\title{
Climate uncertainties and their discontents: increasing the impact of assessments on public understanding of climate risks and choices
}

\author{
Brenda Ekwurzel • Peter C. Frumhoff • \\ James J. McCarthy
}

Received: 31 March 2011 / Accepted: 26 July 2011 / Published online: 9 August 2011

C The Author(s) 2011. This article is published with open access at Springerlink.com

\begin{abstract}
US public awareness of the reality and risks of human-caused climate change remains limited, despite strong evidence presented in the IPCC and other major climate assessments. One contributing factor may be that the immense collective effort to produce periodic climate assessments is typically not well matched with public communication and outreach efforts for these reports, leaving a vacuum to be filled by less authoritative sources. Print and online media coverage provides one metric of the US public reach of selected climate assessments between 2000 and 2010. The number of Lexis-Nexis articles for the search terms "climate change" or "global warming" within 14 days of each report's release varied significantly over time with a peak occurring in 2007. When compared to background "chatter" relating to climate change, each assessment had widely diverse penetration in the US media ( $\sim 4 \%$ for US National Climate Assessment in 2000; 17\% for Arctic Climate Impacts Assessment in 2004; $\sim 19 \%$ and $\sim 10 \%$ for Intergovernmental Panel on Climate Change (IPCC) Fourth Assessment Report Working Group I and Working Group II respectively in 2007; 4\% for the US Global Change Research Program (USGCRP) assessment report in 2009; and $~ 5 \%$ for US National Research Council's America's Climate Choices reports in 2010). We propose ways to improve the public reach of climate assessments, focusing in particular on approaches to more effectively characterize and communicate the role of uncertainty in human actions as distinct from other sources of uncertainty across the range of possible climate futures.
\end{abstract}

\footnotetext{
B. Ekwurzel

Union of Concerned Scientists, 1825 K St. NW, Ste. 800, Washington, DC 20006-1232, USA

P. C. Frumhoff $(\bowtie)$

Union of Concerned Scientists, Two Brattle Square, Cambridge, MA 02138, USA

e-mail: pfrumhoff@ucsusa.org

J. J. McCarthy

Museum of Comparative Zoology, Harvard University, 26 Oxford St., Cambridge, MA 02138, USA
} 


\section{Introduction}

Core scientific understanding that climate change resulting from human activity is underway and poses substantial risks to human and natural systems globally and in United States has been confirmed in multiple assessment reports published over the past decade (e.g. ACIA 2004, IPCC, 2007, Karl et al. 2009, National Research Council 2010a, b, c, d, 2011). Yet US public awareness of this understanding is limited and sharply divided along partisan lines, constraining the American response to climate change. In one recent poll of US public opinion, only 39\% of respondents concurred with the statement that "most scientists think that global warming is happening," while $40 \%$ concurred with the incorrect statement that "there is a lot of disagreement among scientists over whether or not global warming is happening." Only 15\% of respondents knew of the high agreement among climate scientists that "global warming is caused mostly by human activities" (Leiserowitz et al. 2011). In another, 59\% of Democrats were of the opinion that "scientists agree the earth is getting warmer because of human activity", a view held by only $30 \%$ of Republicans (Pew Research Center for People and the Press 2010). This gap between scientific and public understanding of the core findings and implications of climate science is shaped by many factors that lie outside the realm of science, including deliberate efforts to sow confusion about climate science and scientists (Oreskes and Conway, 2010), deeply held values and beliefs that are challenged by scientific findings (Hoffman 2011), and the exceptionally diversified media environment through which different segments of the US public access information.

This gap may also be exacerbated by the ways in which the Intergovernmental Panel on Climate Change (IPCC) and other scientific assessment institutions chose to communicate findings to public audiences. With a few notable exceptions, assessment reports are written and released with the aim of communicating the results to the policymakers that authorize them, and other scientists, with minimal communications and outreach aimed at reaching public audiences (NRC 2007).

Here, we present data indicating that several prominent climate assessments with high relevance to US public understanding of climate science have largely failed to reach US public audiences, leaving a vacuum to be filled by less authoritative voices. We propose several ways in which the IPCC and other climate assessment institutions might improve their public reach in the United States. We focus in particular on recommendations to improve the ways in which assessments characterize and communicate key policy-relevant sources of uncertainty in projections of climate change and reinforce core climate science findings for which public uncertainty is corrosive to informed public policy.

\section{Are climate assessments reaching US public audiences?}

The manner in which a climate assessment is designed, released, and communicated to public audiences might be expected to have an impact on whether and how it reaches them (Cole and Watrous 2007; Franco et al. 2008). Consider, for example, the varying approaches taken by several climate assessments focused all or in part on the United States.

The first US National Climate Assessment (NCA) report was released in the fall of 2000 (National Assessment Synthesis Team 2001). Reflecting the report's intent to reach public audiences, the preamble was direct and clear: "Humanity's influence on the global climate will grow in the 21st century. Increasingly, there will be significant climate-related changes that will affect each one of us" (National Assessment Synthesis Team 2001). But its release, 
on November 11, 2000, came when US national media attention was focused on a contested Presidential election (Justus and Fletcher 2001). There was no official press event and limited outreach (Susan Hassol, pers. comm.; Mooney 2007). One might expect minimal public attention under such circumstances.

The Arctic Climate Impact Assessment's synthesis report Impacts of a Warming Arctic (ACIA 2005) was written with the aid of communications specialists in a clear, direct style, illustrated with compelling photographs and graphics designed for a non-scientist audience, and unveiled at the National Press Club briefing. Several authors engaged in extensive outreach to explain the major findings to public audiences at many subsequent venues.

The 2007 reports released for the IPCC Fourth Assessment Report (AR4) were accompanied by IPCC organized international press conferences. Further US outreach occurred at congressional hearings and briefings featuring IPCC AR4 authors. Many US report authors and non- governmental organizations also helped alert media organizations to the findings of the AR4 and create public-facing outreach materials. For example, the Union of Concerned Scientists (UCS) worked with several AR4 authors to produce fourpage US-focused summaries of each IPCC working group's Summary for Policymakers and distributed them to members of Congress and various public audiences (Ekwurzel and Hassol 2007a; Ekwurzel and Hassol 2007b; Gordon et al., 2007).

The USGCRP 2009 Assessment (Karl et al. 2009) built upon the major findings of USGCRP 21 Synthesis and Assessment Products (USGCRP 2011a) detailing current and projected impacts across major sectors and regions of the United States. It was written and illustrated with the aid of communications specialists to create accessible language and graphics. Its release at a White House press conference in June 2009 was accompanied by a press release and a series of short well-designed outreach documents to highlight findings most relevant to various audiences across regions and climate-sensitive sectors. But in contrast to the ACIA, little public outreach was undertaken beyond the initial release and communication to Congress and federal agencies.

The America's Climate Choices (ACC) reports, produced under the auspices of the National Research Council (NRC 2010a, b, c, d), were designed to meet the NRC's primary mission to advise the government and reach broader audiences as well. ACC authors briefed US federal policymakers after each report was released. In addition, the NRC held press briefings and each report was accompanied by a short outreach-oriented "report in brief." The National Academies also produced and posted on the web videos in which ACC authors described report findings, and coordinated with non-governmental organizations to create opportunities for report authors to discuss findings with broader audiences.

To take a first cut of how well these climate assessments reached US public audiences, we compared the number of times each assessment was reported on in the US print and online media within 14 days of report release, compared with the total number of articles reporting on climate change or global warming (Fig. 1). The specific metric used was a Lexis-Nexis search on the terms "global warming" or "climate change" for U.S. print and online media (excluding blogs and press releases). Articles counted as coverage of each assessment report were manually checked from the Lexis-Nexis output of articles over the same time period.

Total US news coverage of articles mentioning "global warming" or "climate change," an indicator of public exposure to the general topic, is consistent with the general pattern found in Boykoff's (2011) assessment of five leading US newspapers - relatively low in 2004, high in 2007 and declining again by mid-2010.

Total print and on-line media coverage varied widely across assessments. Each was covered by "beat" reporters, individuals assigned to cover climate in a small number of nationally 


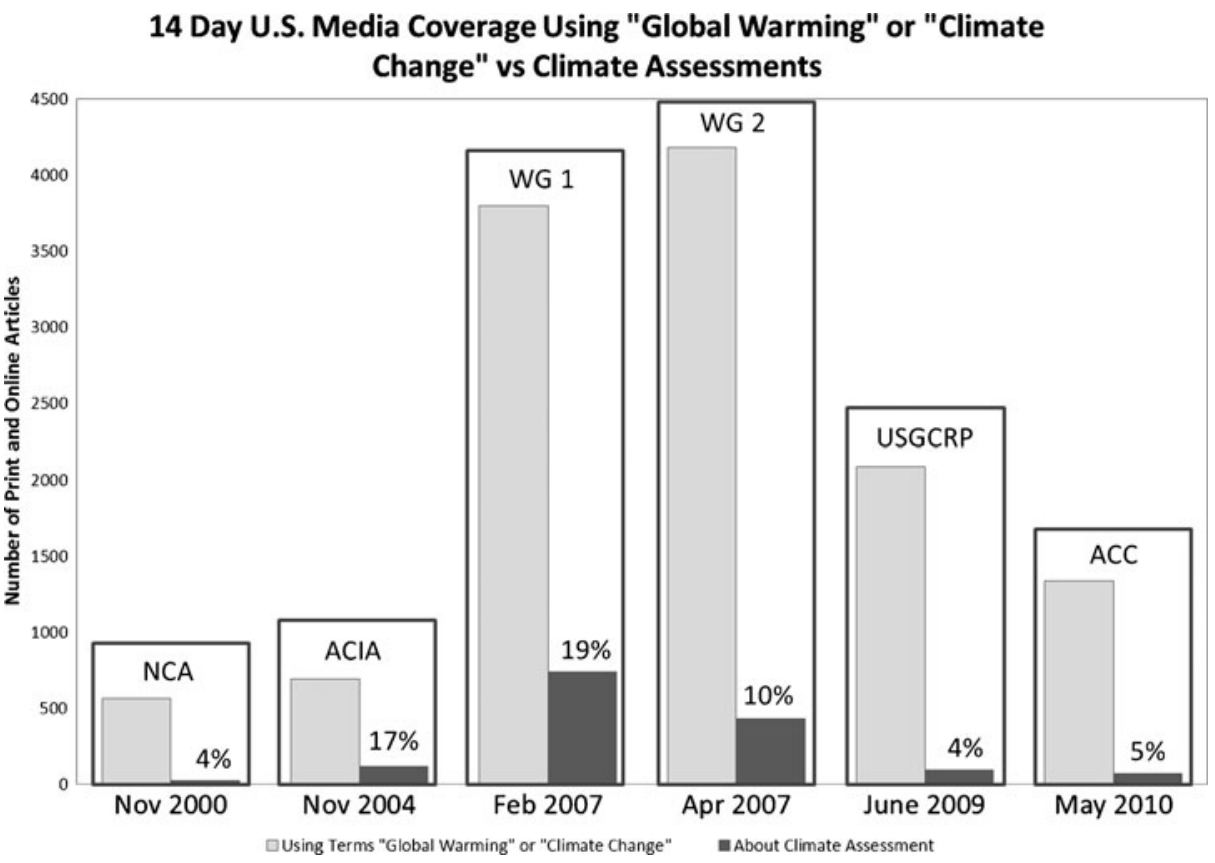

Fig. 1 Number of print and online articles using the terms "global warming" or "climate change" versus articles about a climate assessment, within 14 days of the report release. See text for details. NCA = National Climate Assessment released in November 2000; ACIA = Arctic Climate Impacts Assessment released in November 2004; WG1 = IPCC Fourth Assessment Report (AR4) Working Group 1, released in February 2007; WG2 = IPCC AR4 Working Group 2, released in April 2007; USGCRP = Global Climate Change Impacts in the United States released in June 2009; ACC = America's Climate Choices released in May 2010; GW = Global Warming; $\mathrm{CC}=$ Climate Change

prominent newspapers, wire services and trade publications. But only the IPCC and ACIA reports gained substantial coverage in regional and local print and online media that more firmly raises US public awareness of news (Hayes and Grossman 2006; Dean 2009).

The IPCC AR4 Working Group 1 report received the largest amount of media attention on its release (737 reports over 14 days, $\sim 19 \%$ of all news coverage mentioning "global warming" or "climate change"), with interest tailing off somewhat with the subsequent release of the Working Group 2 report.

In contrast, both the 2000 and 2009 US NCA reports received far less media attention upon release, each receiving $\sim 4 \%$ of climate-change related news coverage (Fig. 1). For the second NCA report (Karl et al. 2009), this low attention is particularly striking. Not only was it focused on US impacts, written in accessible, compelling language, and replete with excellent graphics accompanied by short, well-written outreach documents, it was released at a time when Congress was debating national climate legislation and US media attention on climate was relatively high. Similarly ignored by the US media beyond the major national beat reporters were the NRC reports on America's Climate Choices, released in 2010 (Fig. 1). Remarkably, the Arctic Climate Impacts Assessment, covering impacts far from where most Americans live and released during a period of relatively low US media coverage of climate change (November 2004), received greater total and proportional coverage than the USGCRP Assessments, or the America's Climate Choices over a period of several weeks (Fig. 2). 


\section{U.S. Media Coverage of Assessments Within 60 Days of Release}



Fig. 2 Lexis-Nexis search of United States print and online media 60 days following public release of the Arctic Climate Impact Assessment (ACIA, 2009) in 2004, Global Climate Change Impacts in the United States in 2009 (Karl et al. 2009) and three reports released on the same day for the America's Climate Choices in 2010 (NRC 2010a, b, c)

Many factors may be at play in low media coverage of the 2009 and 2010 US-focused climate assessments (Hayes and Grossman 2006; Hassol 2008; Dean 2009, Olson 2009). One may be that the US administration (in the case of the USGCRP assessment) and the National Research Council (in the case of the America's Climate Choices reports) did not make a vigorous and sustained media focus around these reports a high priority - in sharp contrast to the sustained investment in media and outreach that followed the 2005 ACIA release.

We suggest that the release of these reports were missed opportunities to build US public understanding and confidence in the policy-relevant findings of climate science at a time when prominent US and international policy decisions were being considered amid parallel efforts to sow confusion (Oreskes and Conway 2010; McCright and Dunlap 2010; McCright 2011). Following the November 2009 release, extensive publicity was given to unsubstantiated (and subsequently dismissed as baseless upon independent review) allegations of scientific misconduct in the content of emails stolen from the University of East Anglia's Climatic Research Unit. Intensive blogosphere commentary in January 2010 on an error in the melting rates of Himalayan glaciers discovered in the AR4 Working Group 2 report generated substantial media scrutiny of the scientific integrity of the IPCC, nearly 3 years after the AR4 was released.

US print and on-line coverage of the IPCC "controversy" was considerably lower than original coverage of AR4 Working Group 1 and 2 report releases but higher than USfocused assessments just before and after (Figs. 2 and 3). Polls conducted in the wake of this reporting indicate that such coverage diminished public confidence in the core findings of climate science that have not yet completely rebounded (Leiserowitz et al., 2011). 
U.S. Media Coverage of Assessments Within 60 Days of Release

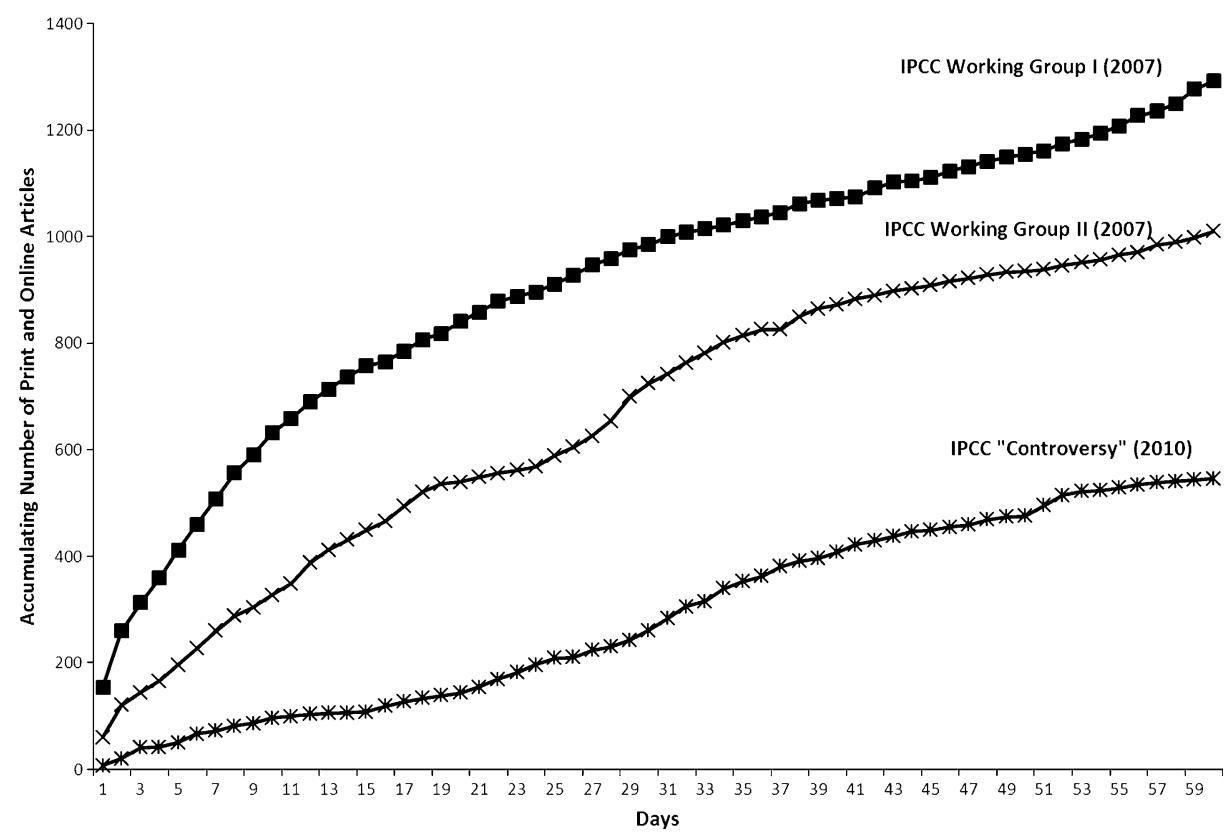

Fig. 3 Media coverage jumped again nearly three years after the IPCC AR4 report release largely from the stories surrounding the WG2 estimates of the timing for nearly complete disappearance of Himalayan glaciers. Abbreviations explained in Fig. 2. The IPCC "controversy" results begin on the day the New York Times and other US print media first reported on the subject (January 19, 2010)

However careful and painstaking the process by which IPCC and other climate assessments are carried out, their policy-relevance will be greatly constrained if the critical work they do is defined in eyes of policymakers and the public by politically savvy detractors who mischaracterize scientific uncertainties and exploit the media's fascination with reporting alleged controversy.

One must assume that efforts to undermine public understanding and confidence in climate science are likely to continue, it is essential that future assessments invest in capacity to more vigorously communicate findings to the media and public audiences in the US and internationally, and swiftly and appropriately respond to questions and criticisms that arise (InterAcademy Council 2010; IPCC 2011). Properly designed and communicated, the IPCC Fifth Assessment report (AR5) due out in 2013-2014 and the next US National Climate Assessment, due out in 2013 (USGCRP 2011b), present key opportunities to strengthen public understanding of core climate science conclusions, as well as legitimate and policy-relevant uncertainties about climate risks and choices.

\section{Strengthening public understanding of policy-relevant uncertainties about climate risks and choices}

The guidance notes for lead authors of the IPCC Fifth Assessment Report (AR5) on the consistent treatment of uncertainties speak to providing a "common and calibrated approach" for "communicating the degree of certainty" of IPCC findings (Mastrandrea et 
al. 2010). Despite heroic efforts by a few authors and abundant good intentions, prior IPCC assessments have failed to adhere to a 'common and calibrated approach' across working groups, an inconsistency that surely has contributed to confusion for both technical and non-technical readers alike. The efforts by Mastrandrea et al. (2010) and the editors of this Special Issue of Climatic Change to build improvements into the AR5 are invaluable. But effectively communicating the degree of certainty and confidence in key findings to nontechnical audiences requires far more than robustly characterizing these qualities in IPCC technical chapters, Summaries for Policymakers and other formal assessment products

\subsection{Uncertainty language as a barrier to public understanding}

The challenge of communicating relative uncertainty in scientific findings to non-technical audiences has been discussed at length by Morgan and colleagues (CCSP 2009). One recent study suggests that many in the US public may be interpreting the probabilities associated with likelihood terms used by the IPCC Fourth Assessment Report (AR4) very differently than intended, even when provided ready access to the IPCC guidelines (Budescu et al. 2009). When presented with excerpted sentences from the AR4, survey respondents consistently underestimated the certainty implied by extremes, such as "very likely" ( $>90 \%$ probability, according to the guidelines) and "very unlikely" ( $<10 \%)$. Twenty-five per cent of respondents, for example, interpreted "very likely," as in "average Northern Hemisphere temperatures during the second half of the $20^{\text {th }}$ century were very likely higher than during any other 50year period in the last 500 years" (IPCC 2007), as meaning less than 70\% probability.

If these results hold more broadly, they have profound implications for public understanding of climate science. Media coverage of IPCC reports characteristically use the IPCC likelihood terms to report out key findings. The Associated Press headline filed on the AR4 Working Group I report release in February 2007 was "Global warming 'very likely' man-made, unstoppable for centuries" (Borenstein 2007). Budescu et al.'s results suggest that a sizable proportion of U.S. public audiences would read "very likely" in a news report to mean "we are not sure." The challenge to convey clearly a measure of certainty magnifies as the IPCC likelihood terms are translated into the other five official UN languages and used in media and outreach venues aimed at policymaker and public audiences across different nations and cultures.

Thus, IPCC terminology intended to succinctly represent authors' consensus on the range of probabilities associated with key findings may itself be a significant barrier to understanding for public and policymaker audiences.

Where levels of certainty can be quantified, public understanding may be better served by consistently coupling likelihood terms with their intended quantitative range (Budescu et al. 2009), or by simply using the standardized suite of direct numerical expressions of probability (Mastrandrea et al. 2010). Where they cannot be quantified, guidance for the AR5 calls for authors to use a confidence scale (from "very low" to "very high") to capture consensus judgments about both the robustness of the scientific data and the degree of agreement among independent lines of evidence (Mastrandrea et al. 2010).

3.2 Making clear the role of human choice as a source of uncertainty in projecting future climate change

Projections of regional-scale climate change have high importance for policymakers, climate-sensitive industries and communities and need to be conveyed in a way that makes key uncertainties clear to non-technical audiences. Uncertainties in climate change 
projections arise from three primary sources: natural climate fluctuations that over relatively short time scales can amplify or moderate trends resulting from anthropogenic climate change; uncertainties in the climate system's response to a given level of radiative forcing, which is reflected in the range of responses incorporated into global climate model simulations; and uncertainties in future emissions of heat-trapping gases by human society, and thus the scale of future radiative forcing. The relative importance of these sources varies across regions, climate indicators and forecast lead times (Hawkins and Sutton 2009, 2011) For example, uncertainties over the scale and timing of further emissions is the dominant constraint on our ability to project the extent to which decadal average surface temperature is likely to rise in most regions of the globe beyond the next few decades (Fig. 4; Hawkins and Sutton 2009). Public understanding and informed public policy will

\section{Sources of Uncertainty}

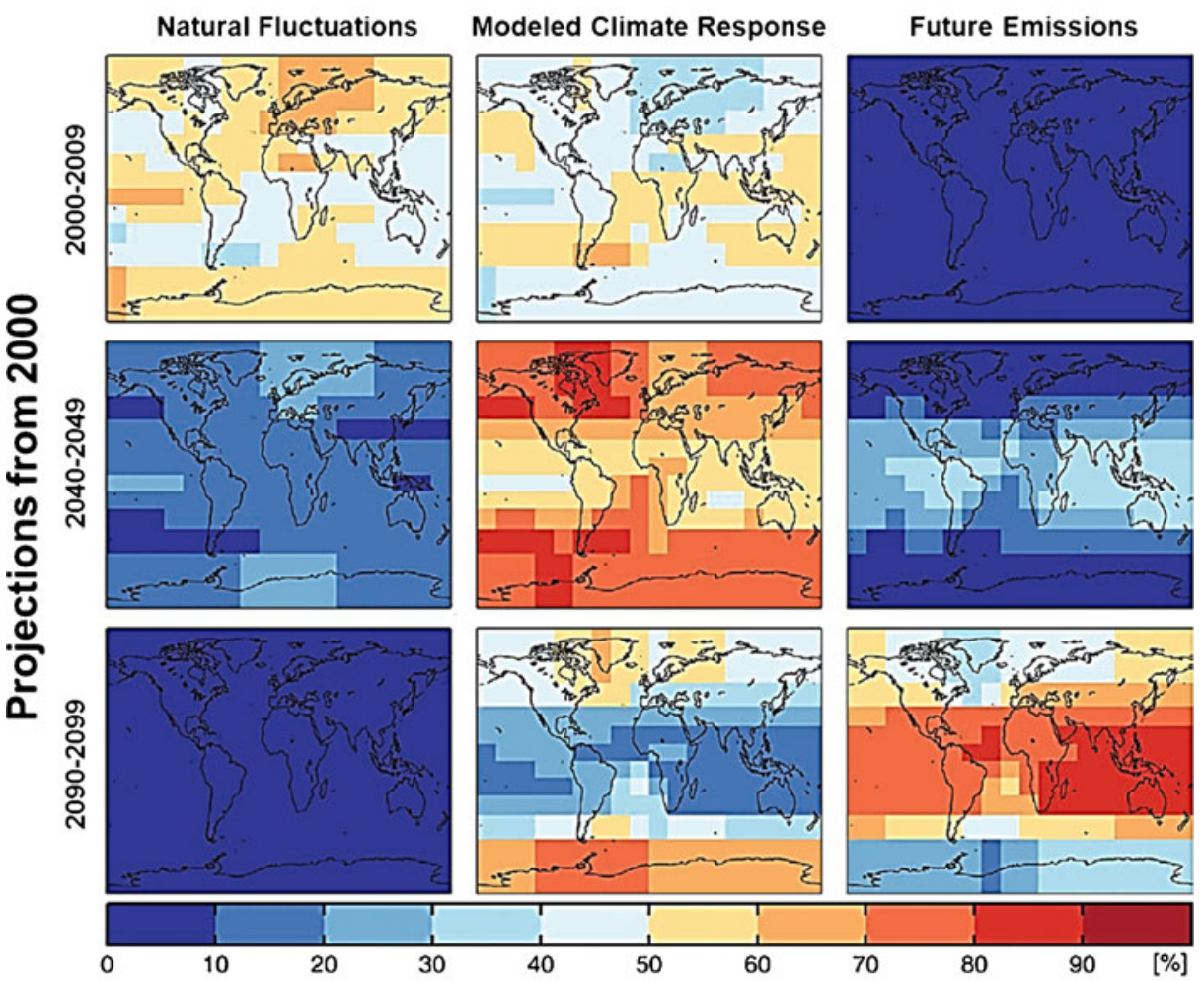

The proportion of uncertainty in projections of decadal surface average temperature arising from different sources. Adapted from Hawkins and Sutton (2009).

Fig. 4 The relative importance of different sources of uncertainty in projections of decadal average surface temperature, across regions and forecast lead times. Figure shows the proportion of uncertainty arising from (i) natural climate fluctuations, (ii) uncertainties in the modeled climate system's response to a given level of radiative forcing, and (iii) uncertainties in the scale and timing of future emissions. Adapted from Hawkins and Sutton (2009), based on comparisons of 15 global climate models and three SRES scenarios, from 20002100. Beyond the next few decades, uncertainties over further human-caused emissions is the dominant constraint on our ability to project the extent to which decadal average surface temperature will rise in most regions of the globe. Differences across models in resolving climate feedbacks remain a major source of uncertainty in projections at high latitudes 
be well-served by a greater emphasis in future assessments on distinguishing among these sources of uncertainty across regions, climate indicators and forecast lead times, and clearly communicating them in public-facing assessment documents. Current practice varies widely. The Summary for Policymakers of the IPCC AR4 Working Group 1 report, for example, describes uncertainties in climate projections but does not as clearly tease apart sources with language or graphics accessible to non-technical audiences.

By contrast, the human emissions choice dimension of uncertainty was a central organizing feature of several regional-scale climate assessments in the United States (Hayhoe et al. 2004, Frumhoff et al. 2007) that coupled synthesis and outreach to inform public understanding and policy choices regarding mitigation as well as adaptation (Franco et al. 2008). The 2009 USGCRP Assessment (Karl et al. 2009) was also explicit in its conclusion that "the amount and rate of future climate change depend primarily on current and future human-caused emissions of heat-trapping gases and airborne particles" and coupled clear language with equally clear, visually compelling graphics highlighting the role of human choice (Fig. 5a). In contrast, a similar effort to communicate to US public audiences extreme heat findings of an NRC report on the impacts of different possible

a
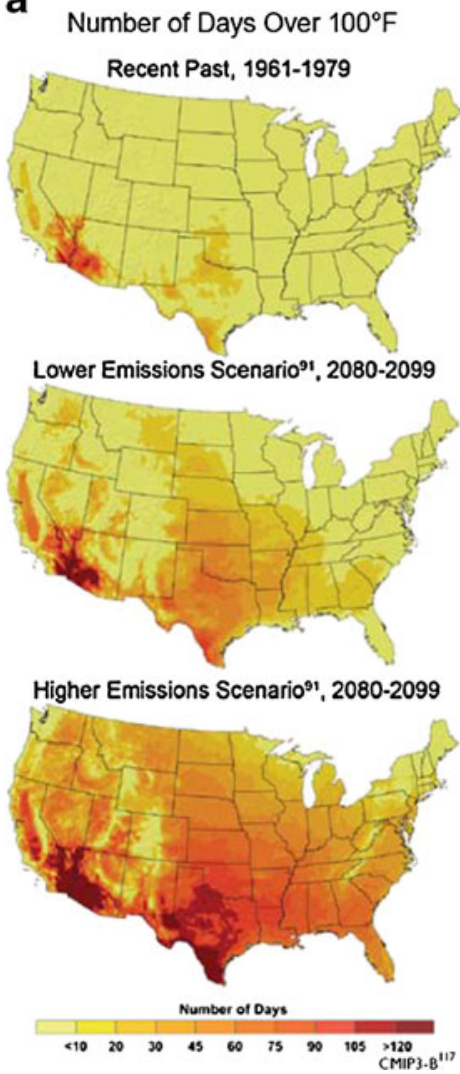

b

\section{Increases in the Duration of Heat Waves}



Fig. 5 Two images intended to convey choice and future consequences to non-technical audiences. Fig 5a contrasts projected days over $100^{\circ}$ fahrenheit (for US audiences) under lower and higher emissions scenarios used by the IPCC and based on a multi-model average (Karl et al. 2009) that can be readily understood. In contrast, Figure 5b, used in an NRC outreach document on climate stabilization (NRC 2011) is too abstruse for non-technical audiences 
choices regarding long-term climate stabilization targets (NRC 2011) did so in some cases with unfortunately abstruse graphics (Fig. 5b).

Of course, limited time, uncertain and restricted budgets, competing demands for attention of authors, and, perhaps reluctance to be highly visible in the face of anticipated attacks on both the scientific findings and the reputations of assessment authors may all act to constrain climate assessments from fully realizing their potential to educate and engage public audiences in understanding climate risks and choices. But if an informed US electorate is a precondition for effective climate policy in the United States and internationally, then every effort must be made to overcome these constraints and ensure that robust, accessible assessments inform a meaningful public dialogue.

Acknowledgements We thank Christina A. Elles, Olivia V. Ambrogio, and Jeanie Taylor for research support and Susan J. Hassol, Rich Hayes, Sarah Goldberg, Aaron Huertas, Helene Ferranti and Susanne C. Moser for discussion and review. We appreciate the suggestions by anonymous reviewers. This work was generously supported in part by grants from the Grantham Foundation for the Protection of the Environment and the Energy Foundation to the Union of Concerned Scientists.

Open Access This article is distributed under the terms of the Creative Commons Attribution Noncommercial License which permits any noncommercial use, distribution, and reproduction in any medium, provided the original author(s) and source are credited.

\section{References}

ACIA (2004) Arctic climate impact assessment: impacts of a warming arctic. Cambridge University Press, Cambridge

ACIA (2005) Arctic climate impact assessment. Cambridge University Press, New York

Borenstein S (2007) Global warming "very likely" man-made, unstoppable for centuries. Associated Press Archive, February 2, 2007 http://www.aparchive.com/ . Accessed 19 April 2011.

Boykoff M (2011) 2000-2011 US newspaper coverage of climate change or global warming. Center for Science and Technology Policy Research. Sciencepolicy.colorado.edu/media_coverage/us/us_feb2011. jpg. Accessed 11 April 2011

Budescu DV, Broomell S, Por H-H (2009) Improving communication of uncertainty in the reports of the intergovernmental panel on climate change. Psychol Sci 20:299-308

CCSP (2009) Best practice approaches for characterizing, communicating, and incorporating scientific uncertainty in decision making. M. Granger Morgan, Hadi Dowlatabadi, Max Henrion, David Keith, Robert Lempert, Sandra McBride, Mitchell Small, and Thomas Wilbanks (eds.). Synthesis and Assessment Product 5.2 by the Climate Change Science Program and the Subcommittee on Global Change Research. National Oceanic and Atmospheric Administration, Washington, DC

Cole N, Watrous S (2007) Across the great divide: supporting scientists as effective messengers in the public sphere. In: Moser SC, Dilling L (eds) Creating a climate for change: communicating climate change and facilitating social change. Cambridge University Press, Cambridge, pp 180-198

Dean C (2009) Am I making myself clear? A scientist's guide to talking to the public. Harvard University Press, Cambridge, pp 97-109

Ekwurzel B, Hassol SJ (2007a) Findings of the IPCC Fourth Assessment Report: Climate Change Science. February 2007. http://www.ucsusa.org/assets/documents/global_warming/IPCC-WGI-UCS-summary300dpi.pdf. Accessed 11 July 2011

Ekwurzel B, Hassol SJ (2007b) Findings of the IPCC Fourth Assessment Report: Climate Change Impacts. May 2007. http://www.ucsusa.org/assets/documents/global_warming/ucs-ipcc-wg2-72pi-2007.pdf. Accessed 11 July 2011

Franco G, Cayan D, Luers A, Hanemann M, Croes B (2008) Linking climate change science with policy in California. Clim Change 87:S7-S20

Frumhoff PC, McCarthy JJ, Melillo JM, Moser SC, Wuebbles DJ (2007) Confronting climate change in the US Northeast: science, impact, solutions, report of the northeast climate assessment impacts synthesis team. Union of Concerned Scientists, Cambridge 
Gordon D., S.J. Hassol and B. Ekwurzel (2007) Findings of the IPCC Fourth Assessment Report: Climate Change Mitigation. http://www.ucsusa.org/assets/documents/global_warming/IPCC-WGI-UCS-summary300dpi.pdf. Accessed 11 July 2011

Hayes R, Grossman D (2006) A Scientist's guide to talking with the media. Rutgers University Press, New Brunswick

Hayhoe K, Cayan D et al (2004) Emissions pathways, climate change, and impacts on California. Proc Natl Acad Sci USA 101(34):12422-12427

Hawkins E, Sutton R (2009) The potential to narrow uncertainty in regional climate predictions. BAMS 90:1095-1107

Hawkins E, Sutton R (2011) The potential to narrow uncertainty in projections of regional precipitation change. Clim Dynamics 37:407-418

Hoffmann AJ (2011) The growing climate divide. Nature Clim Change 1:195-196

InterAcademy Council (2010) Climate change assessments: Review of the processes and procedures of the IPCC. Committee to Review the intergovernmental panel on climate change. InterAcademy Council. October

IPCC (2007) Summary for Policymakers. In: Climate Change 2007: The Physical Science Basis. Contribution of Working Group I to the Fourth Assessment Report of the Intergovernmental Panel on Climate Change [Solomon, S., D. Qin, M. Manning, Z. Chen, M. Marquis, K.B. Averyt, M.Tignor and H.L. Miller (eds.)]. Cambridge University Press, Cambridge, United Kingdom and New York, NY, USA.

IPCC (2011) Communications Strategy, IPCC $33^{\text {rd }}$ Session, 10-13 May 2011, Abu Dhabi. http://www.ipcc. ch/meetings/session33/ipcc_p33_decisions_taken_comm_strategy.pdf. Accessed 13 July 2011

Justus, JR, Fletcher SR (2001) Global Climate Change, CRS Issue Brief for Congress IB89005, December 14, 2001, Library of Congress 17 pp. http://assets.opencrs.com/rpts/IB89005_20011214.pdf. Accessed 11 July 2011

Karl T, Melillo J, Peterson T (2009) Global climate change impacts in the United States. Cambridge University Press, New York

Leiserowitz A, Maibach, E, Roser-Renouf, C. Smith, N (2011). Climate change in theAmerican Mind: Americans' global warming beliefs and attitudes in May 2011. Yale University and George Mason University. New Haven, CT: Yale Project on Climate Change Communication.

Mastrandrea MD, Field CB, Stocker TF, Edenhofer O, Ebi KL, Frame DJ et al (2010) Guidance notes for lead authors of the IPCC fifth assessment report on consistent treatment of uncertainties. Intergovernmental Panel on Climate Change

McCright AM (2011) Political orientation moderates Americans' beliefs and concern about climate change. Clim Change 104(2):243-253

McCright AM, Dunlap RE (2010) Anti-reflexivity: the American conservative movement's success in undermining climate science and policy. Theor Cult Soc 27(2-3):100-133

Mooney C (2007) An inconvenient assessment. Bulletin of the Atomic Scientists 63: 40-47, 63

National Assessment Synthesis Team (2001) Climate change impacts on the United States: the potential consequences of climate variability and change, report for the US global change research program. Cambridge University Press, Cambridge

National Research Council (2007) Analysis of Global Change Assessments: Lessons Learned. National Academies Press, Washington DC.

National Research Council (2010a) America's climate choices: advancing the science of climate change. National Academies Press, Washington DC; Press release. http://www8.nationalacademies.org/onpinews/ newsitem.aspx?RecordID=05192010. Accessed 11 July 2011

National Research Council (2010b) America's climate choices: limiting the magnitude of future climate change. National Academies Press, Washington DC; Press release. http://www8.nationalacademies.org/ onpinews/newsitem.aspx?RecordID=05192010. Accessed 11 July 2011

National Research Council (2010c) America's climate choices: adapting to the impacts of climate change. National Academies Press, Washington DC; Press release. http://www8.nationalacademies.org/onpinews/ newsitem.aspx?RecordID $=05192010$. Accessed July 11, 2011

National Research Council (2010d) America's climate choices: informing on effective response to climate change. National Academies Press. Washington DC Press release. http://www8.nationalacademies.org/ onpinews/newsitem.aspx?RecordID $=12784$. Accessed 11 July 2011

National Research Council (2011) Warming world: impacts by degree. National Academies Press, Washington

Olson R (2009) Don't be such a scientist: talking substance in an age of style. Island Press, Washington

Oreskes N, Conway EM (2010) Defeating the merchants of doubt. Nature 465(7299):686-687

Pew Research Center for People and the Press (2010) Little Change in Opinions about Global Warming. http://people-press.org/files/legacy-pdf/669.pdf. Accessed 6 July 2011. 
USGCRP (2009) Climate Change Impacts on the United States: The Potential Consequences of Climate Variability and Change and associated documents. http://www.gcrio.org/orders/product_info.php? products id=234\&osCsid=rkkquma24cifuhhvsilh3o7ck2. Accessed 11 July 2011.

USGCRP (2011a). 21 Synthesis and Assessment Products released between 2006 and 2009. http://www. globalchange.gov/publications/reports/scientific-assessments/saps. Accessed 11 July 2011

USGCRP (2011b). The National Climate Assessment. http:/www.globalchange.gov/index.php?option=com content\&view=article\&id=417\&Itemid=401. Accessed 19 April 2011 